Section Editor

Mitchell S.V. Elkind, MD, MS

Mathula Thangarajh, MD, PhD

Soe Soe Mar, MD

Correspondence \& reprint requests to Dr. Thangarajh: thangarajhm@neuro.wustl.edu
Teaching NeuroImages:

\section{CNS involvement in systemic anaplastic large-cell lymphoma}

Figure $1 \quad$ Brain MRI of a child who presented with CNS involvement of systemic anaplastic large-cell lymphoma

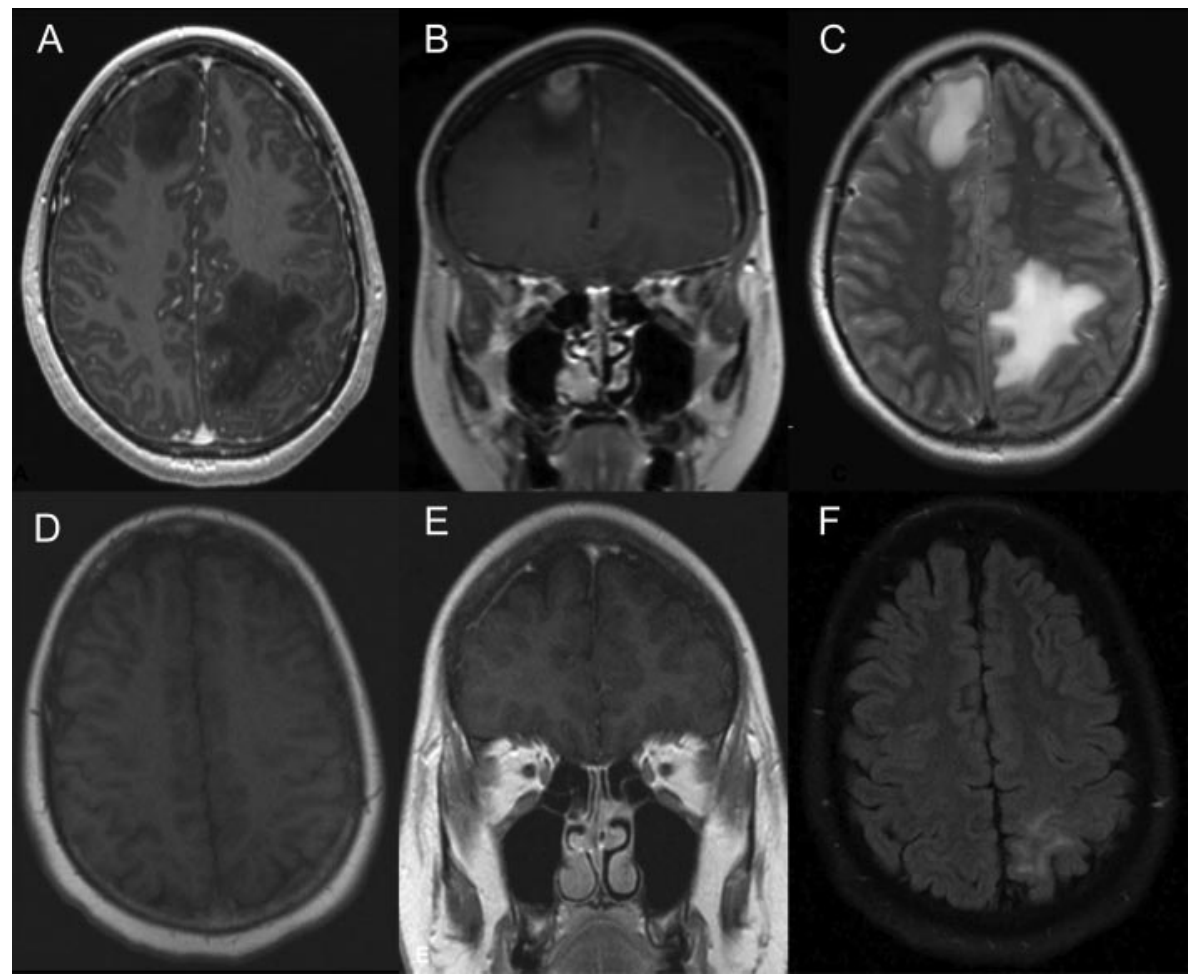

Postgadolinium axial (A) and coronal (B) sections of T1- and axial T2-weighted (C) images showed multiple parenchymal lesions and dura-based lesion, and vasogenic edema at initial admission to the hospital. At 2-year follow-up, the axial (D) and coronal (E) sections of T1 images show resolution of the lesions. T2-weighted image (F) shows gliosis.

An 11-year-old boy presented with acute dysarthria and right hemiparesis. Brain MRI showed multiple enhancing supratentorial lesions (figure 1, A-C). An extensive infectious workup, CSF cytology, whole-body CT, and gallium and PET scans were unremarkable. Diagnostic brain biopsy revealed reactive astrocytosis. He improved gradually with oral prednisone and azathioprine but returned 3 months later with abdominal pain, persistent vomiting, and generalized lymphadenopathy. Brain MRI showed no new lesions. A mesenteric lymph node biopsy showed hallmark cells consistent with anaplastic large-cell lymphoma (figure 2). Intrathecal methotrexate and whole-cranial irradia- tion resulted in radiologic resolution of lesions (figure 1, D-F). CNS involvement in CD30+ ALK+ anaplastic large-cell lymphoma is extremely rare. ${ }^{1,2}$

\section{AUTHOR CONTRIBUTIONS}

Drs. Thangarajh and Mar were involved in data acquisition and data interpretation. Dr. Thangarajh prepared the manuscript.

\section{REFERENCES}

1. Stein H, Foss HD, Dürkop H, et al. CD30(+) anaplastic large cell lymphoma: a review of its histopathologic, genetic, and clinical features. Blood 2000;96:3681-3695.

2. Zhang X, Bui MM, Caracciolo J, Field TL, Zhang L. Adult anaplastic large cell lymphoma involving the central nervous system: a rare clinical scenario. Ann Hematol 2011;90:721-723. 


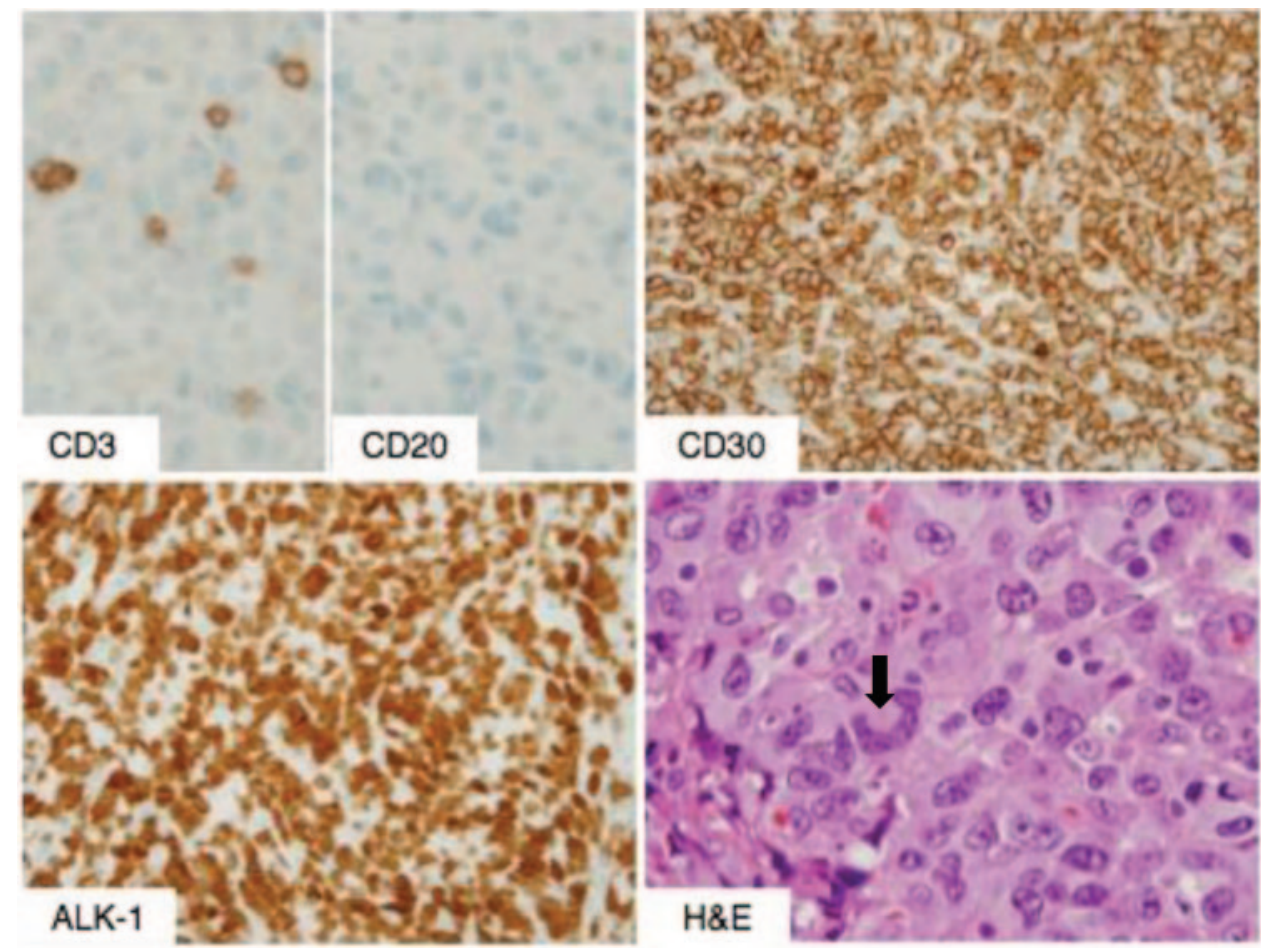

Mesenteric lymph node biopsy showed that the tumor cells were null phenotype (CD 3 and CD20 negative), and positive for CD30 and ALK-1. The characteristic hallmark cell (arrow) seen in anaplastic large-cell lymphoma was present on hematoxylin \& eosin staining. 


\section{Neurology}

\section{Teaching NeuroImages: CNS involvement in systemic anaplastic large-cell lymphoma Mathula Thangarajh and Soe Soe Mar \\ Neurology 2012;79;e74-e75 \\ DOI 10.1212/WNL.0b013e3182661fc1}

This information is current as of August 20, 2012

\author{
Updated Information \& \\ Services
}

References

Subspecialty Collections

Permissions \& Licensing

Reprints including high resolution figures, can be found at: http://n.neurology.org/content/79/8/e74.full

This article cites 2 articles, 1 of which you can access for free at: http://n.neurology.org/content/79/8/e74.full\#ref-list-1

This article, along with others on similar topics, appears in the following collection(s):

All Medical/Systemic disease

http://n.neurology.org/cgi/collection/all_medical_systemic_disease All Pediatric

http://n.neurology.org/cgi/collection/all_pediatric

MRI

http://n.neurology.org/cgi/collection/mri

Information about reproducing this article in parts (figures,tables) or in its entirety can be found online at:

http://www.neurology.org/about/about_the_journal\#permissions

Information about ordering reprints can be found online:

http://n.neurology.org/subscribers/advertise

Neurology ${ }^{\circledR}$ is the official journal of the American Academy of Neurology. Published continuously since 1951, it is now a weekly with 48 issues per year. Copyright Copyright (? 2012 by AAN Enterprises, Inc.. All rights reserved. Print ISSN: 0028-3878. Online ISSN: 1526-632X.

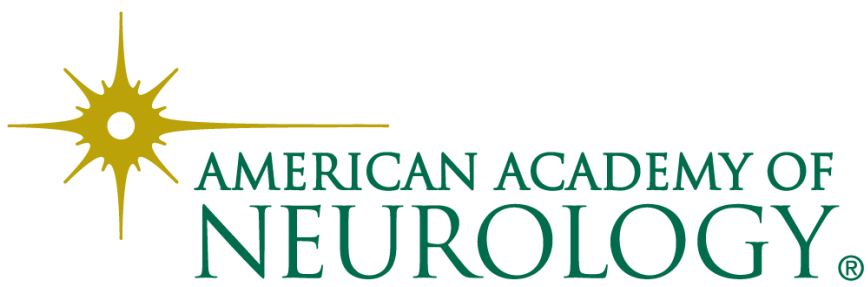

